\title{
KINERJA PARKIR DAN TINGKAT KEPUASAN PENGGUNA JASA LAHAN PARKIR PADA STASIUN KERETA API RAMBIPUJI (DAOP IX JEMBER)
}

\author{
Fadhil Aditya Putra Vidiyanto Amri Gunasti ; Irawati., \\ Program Studi Teknik Sipil, Fakultas Teknik, Universitas Muhammadiyah Jember \\ Jalan Karimata 49, Jember 68172, Indonesia \\ Email : fadhilp8@gmail.com
}

\begin{abstract}
Infrastructure repair railway station was a special transportation infrastructure or separated by ground transportation network system to another. Train services badly needed community as economical transport compared with other transport. Rambipuji station is class II stations included in the operating Area IX Jember. At the train station in improving service required spatial or good facilities. Such as parking spaces for vehicles, a passenger waiting room, warehouse loading and unloading of goods as well as other facilities. The purpose of this research is to know the characteristics and performance of service knowing parking spaces Rambipuji station.

In this research, to know the characteristics of parking in Rambipuji station is by using methods of observation and analysis calculation, while to know the level of satisfaction of parking lot users using Quisioner method Service Quality. In both these methods, all have a portion of its interests. The method of observation and analysis of calculations is used to know all the characteristics of parking available at Rambipuji station, while Quisioner Service Quality method is for the measurement of the preconception of users of parking Conducted by spreading Quisioner to 49 respondents to know the value of expectations and actual value of Performance received by train passengers Rambipuji.
\end{abstract}

Keywords: Parking space, parking lot characteristics, parking lot user satisfaction, parking space needs, Rambipuji station, Test $Z$. 


\section{PENDAHULUAN}

Prasarana Stasiun

Kereta api merupakan prasarana transportasi khusus atau dipisahkan dengan sistem jaringan transportasi darat yang lain. Stasiun Kereta api mempunyai fungsi yang berbeda dengan prasarana lainnya, seperti Terminal Bus, Bandar udara/lapagan terbang, dan lain sebagainya. Stasiun Kereta api selain berfungsi sebagai tempat naik turunnya penumpang/barang, juga sebagai tempat perawatan gerbong dan lokomotif. Selain itu, Stasiun Kereta api sebagai tempat pergantian atau penyambungan gerbong dengan tujuan yang sesuai dengan jaringan yang disediakan. Pada jasa angkutan Kereta api sangat dibutuhkan masyarakat sebagai angkutan ekonomis dibanding dengan angkutan lainnya.

Stasiunrambipuji merupakan stasiun kereta api kelas II yang terletak di JalanDarmawangsa Rambipuji Jember.

Stasiun Kereta api ini terletak pada ketinggian +52 meter ini termasuk dalam Daerah Operasi IX Jember. Stasiun ini memiliki lima jalur kereta api dengan jalur 3 sebagai sepur lurus, jalur 1 dan 2 untuk persilangan atau persusulan kereta api, serta jalur 4 dan 5 untuk parkir kereta api barang yang mana dahulu terdapat fasilitas peti kemas yang sekarang sudah tidak beroperasi lagi. (Sumber : Wikipedia, 2018).

Pada Stasiun Kereta api dalam meningkatkan pelayanan, diperlukan tata ruang atau fasilitas yang baik. Seperti ruang parkir kendaraan, ruang tunggu penumpang, gudang bongkar muat barang, maupun fasilitas lainnya. Dengan pelayanan yang baik, diharapkan jasa transortasi ini dapat memberikan kelancaran, kenyamanan dan keamanan bagi pengguna jasa.

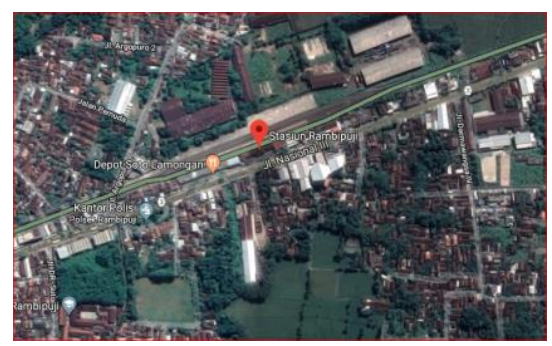

Gambar. 1.1 Lokasi Penelitian Tugas Akhir
Berdasarkan latar belakang yang dijelaskan sebelumnya maka dalam kesempatan Tugas Akhir kali ini, akan mengambil topik permasalahan tentang kinerja parkir dan tingkat kepuasan pengguna ruang parkir pada Stasiun Kereta api Rambipuji Jember (Daop IX).

\subsection{Rumusan masalah.}

Rumusan masalah yang akan dibahas antara lain :

1. Bagaimana kapasitas daya tampung lahan parkir dan karakteristik parkir (akumulasi, durasi, tingkat pergantian parkir dan indeks parkir) kendaraan bermotor yang ada di Stasiun Kereta api Rambipuji Jember?

2. Bagaimana perbedaan antara kenyataan di lapangan dengan harapan penumpang terhadap layanan parkir yang ada di Stasiun Rambipuji ?

3. Bagaimana hasil dari uji $\mathrm{z}$ pada keseluruhan indikator ?

\subsection{Batasan Masalah}

Batasan masalah dalam pembahasan ini ialah :

1. Analisa yang dilakukan tidak membahas kebutuhan lahan parkir 5 tahun kedepan, karakteristik parkir, kapasitas daya tampung area parkir Stasiun Kereta api Rambipuji Jember.

2. Mengidentifikasi tingkat kepuasan penumpang yg menggunakan tempat parkir Stasiun Kereta api Rambipuji Jember dengan berupa data kuisioner. Dalam penelitian ini bentuk kuisioner untuk mengidentifikasi tingkat kepuasan pengguna jasa berdasarkan Peraturan Menteri Perhubungan No. 47 Tahun 2014. Metode yang digunakan untuk mengolah data tingkat kepuasan penumpang yg menggunakan tempat parkir Stasiun Kereta api Rambipuji Jember adalah dengan metode Service Quality (Servqual).

3. Penelitian ini hanya dilakukan pada pukul 08.00-17.00 dikarenakan pada surat yang di terbitkan PT Kereta Api Daerah Operasi 9 Jember hanya diijinkan pada jam tersebut.

\subsection{Tujuan Penelitian}


Adapun tujuan yang ingin dicapai antara lain:

1. Untuk mengetahui kapasitas daya tampung area parkir dan menghitung jumlah kendaraan bermotor per hari di dalam Stasiun Kereta api Rambipuji Jember.

2. Untuk mengetahui karakteristik parkir (akumulasi, durasi masing masing kendaraan, tingkat pergantian ruang parkir dan indeks parkir) kendaraan bermotor di area parkir Stasiun Kereta api Rambipuji Jember.

3. Mengevaluasi kinerja pelayanan ruang parkir Stasiun Rambipuji Jember menggunakan metode Service Quality (Servqual).

\subsection{Manfaat Penulisan}

Adapun manfaat dari pembahasan ini ialah :

a. Teoritis.

Diharapkan dapat memberikan manfaat dan informasi secara lebih detail tentang fasilitas serta tata ruang Stasiun Kereta api Rambipuji Jember (Daop IX).

b. Praktis

Dari hasil penelitian di Stasiun Kereta api Rambipuji Jember (Daop IX) maka diharapkan dapat memberikan gambaran tentang kondisi area parkir stasiun Kereta api Rambipuji pada saat ini dan untuk melakukan perbaikan secara pelayanan Stasiun Kereta api Rambipuji (Daop IX) kedepannya.

\section{TINJAUAN PUSTAKA}

\subsection{Kereta Api Indonesia}

Kereta api adalah sarana transportasi berupa kendaraan tenaga Diesel atau listrik yang terdiri atas rangkaian gerbong yang ditarik oleh lokomotif dan berjalan di atas rel atau rentangan baja (KBBI). Menurut Peraturan Menteri Perhubungan No. 47 Tahun 2014, Kereta api adalah sarana perkeretaapian dengan tenaga gerak, baik berjalan sendiri maupun dirangkaikan dengan sarana perkeretaapian lainnya yang akan ataupun sedang bergerak di jalan rel yang terkait dengan perjalanan kereta api. Kereta api dibagi dalam berbagai macam
(Sumber : Taufan Abadi, Jalan Kereta Api, Unmuh Jember, 2016) :
a. Kereta api penumpang
b. Kereta api barang
c. Kereta api campuran
d. Kereta api kerja
e. Kereta api pertolongan

\subsection{Perkerataapian di Indonesia}

$$
\text { Berdasarkan Undang-undang }
$$

Republik Indonesia No.23 Tahun 2007, perkeretaapian adalah satu kesatuan sistem yang terdiri atas prasarana, sarana, dan sumber daya manusia, serta norma, kriteria, persyaratan dan prosedur untuk penyelenggaraan transportasi kereta api. Dalam pasal 3 Undangundang No.23 Tahun 2007 bahwa perkeretaapian diselenggarakan dengan tujuan untuk memperlancar perpindahan orang dan/atau barang secara massal dengan selamat, aman, nyaman, cepat dan lancar, tepat, tertib dan teratur, efisien serta menunjang pemerataan, pertumbuhan, stabilitas, pendorong dan penggerak pembangunan Nasional Indonesia.

\subsection{Stasiun Kereta Api Indonesia}

Pengertian Stasiun menurut Peraturan Menteri Perhubungan No. 32 Tahun 2011, merupakan prasarana atau tempat bagi penumpang naik kereta api dan sebagai tempat pemberhentian kereta api. Disebutkan dalam pasal 35 bahwa stasiun kereta api berfungsi sebagai tempat kereta api berangkat atau berhenti untuk melayani naik turun penumpang, bongkar muat barang, dan/atau keperluan operasi kereta api. Stasiun untuk keperluan naik turun penumpang sekurang-kurangnya dilengkapi fasilitas (buku Taufan Abadi, Jalan Rel Kereta Api, unmuh Jember, 2016) :

1. Keselamatan,

2. Keamanan,

3. Kenyamanan,

4. Naik turun penumpang,

5. Penyandang cacat,

6. Kesehatan,

7. Fasilitas umum. 
Bangunan stasiun kereta api itu sendiri pada umumnya terdiri atas bagian- bagian sebagai berikut (Triwinarto, 1997) :

1. Halaman depan/Front area

Tempat ini berfungsi sebagai perpindahan dari sistem transportasi jalan baja ke sistem transportasi jalan raya atau sebaliknya. Tempat ini berupa:

a. Terminal kendaraan umum.

b. Parkir kendaraan,

c. Bongkar muat barang.

2. Bangunan Stasiun

Bangunan ini biasanya terdiri atas :

a. Ruang depan (hall atau vestibule) loket,

b. Fasilitas administratif (kantor kepala stasiun \& staff),

c. Fasilitas operasional (ruang sinyal, ruang teknik),

d. Kantin dan toilet umum.

3. Peron

Peron terdiri atas:

a. Tempat tunggu,

b. Naik-turun dari dan menuju kereta api,

c. Tempat bongkat muat barang. Bagian ini bisa beratap atau tidak.

4. Emplasemen

Emplasmen tediri atas:

a. Sepur lurus,

b. Peron

c. Sepur belok sebagai tempat kereta api untuk memberi kesempatan kereta lain lewat.

2.13 Kapasitas dan Derajat Kejenuhan Jalan

Nilai Kapasitas jalan MKJI (1997)

didefinisikan sebagai arus maksimum melalui suatu titik di jalan yang dapat dipertahankan per satuan jamnya pada kondisi tertentu. Untuk jalan dua-lajur dua-arah, kapasitas ditentukan untuk arus dua arah ( kkombinasi dua arah ), tetapi untuk jalan dengan banyak lajur, arus dipisahkan per arah dan kapasitas ditentukan per lajur (satu jalan).

Untuk nilai kapasitas telah diamati melalui pengumpulan data lapangan selama memungkinkan. Karena lokasi yang mempunyai arus mendekati kapasitas segmenjalan sedikit (sebagaimana terlihat dari mkapasitas simpang sepanjang jalan), kapasitas juga telah diperkirakan dari analisa kondisi iringan lalu lintas, dan secara teoritis dengan mengasumsikan hubungan matematik antara kerapatan, kecepatan dan arus. Kapasitas jalan luar kota di Indonesia dapat dihitung menggunakan persamaan MKJI (1997:18).

Sedangkan perhitungan derajat kejenuhannya dapat dihitung dengan rumus :

DS = Qsmp / C

Dengan :

C : Kapasitas

DS : Derajat Kejenuhan

Qsmp : Volume Kendaraan.

\subsection{Kualitas Layanan Pengguna Jasa}

Pengertian kualitas layanan (sumber : http://www.academia.edu) merupakan penciptaan superior value bagi pelanggan untuk meningkatkan kinerja bisnis/pemasaran perusahaan. Menurut Zeithmal dan Bitner (2000) bahwa kualitas layanan adalah total pengalaman yang hanya dapat di evaluasi oleh pelanggan. Sedangkan kualitas jasa adalah tingkat keunggulan yang diharapkan dan pengendalian atas tingkat keunggulan untuk memenuhi keinginan pelanggan. Gaspersz (2002) menyebutkan ada 9 dimensi untuk perbaikan kualitas layanan yaitu:

Ketepatan waktu pelayanan (waktu tunggu dan waktu proses).

1. Kesopanan dan keramahan dalam memberikan pelayanan langsung dengan pelanggan eksternal.

2. Tanggung jawab dalam penerimaan pesanan dan penanganan keluhan dari pelanggan ekternal.

3. Kelengkapan pelayanan dan sarana pendukung serta pelengkap lainnya.

4. Kemudahan mendapatkan pelayanan (banyaknya outlet, petugas, staf administrasi dll).

5. Variasi model pelayanan (inovasi pelayanan, feature dari pelayanan).

6. Pelayanan pribadi (permintaan khusus). 
7. Atribut pendukung pelayanan lainnya seperti kebersihan, lingkungan, ruang tunggu, music, $\mathrm{AC}$ dan lain-lain.

8. Tanggung jawab dalam penerimaan pesanan dan penanganan keluhan dari pelanggan ekternal.

9. Kelengkapan pelayanan dan sarana pendukung serta pelengkap lainnya.

10.Kemudahan mendapatkan pelayanan (banyaknya outlet, petugas, staf administrasi dll).

11.Variasi model pelayanan (inovasi pelayanan, feature dari pelayanan).

12.Pelayanan pribadi (permintaan khusus).

13. Atribut pendukung pelayanan lainnya seperti kebersihan, lingkungan, ruang tunggu, music, AC dan lain-lain.

14. Kenyamanan dalam memperoleh pelayanan seperti tempat parkir, ketersediaan informasi, ruang pelayanan dll.

\subsection{Pengertian Parkir}

Pengertian parkir adalah keadaan tidak bergerak suatu kendaraan yang tidak bersifat sementara. Parkir merupakan salah satu komponen suatu sistem transportasi yang perlu dipertimbangkan dan diperhatikan. Pada kotakota besar area parkir merupakan salah satu kebutuhan bagi pemilk kendaraan. Dengan demikian perencanaan fasilitas parkir adalah suatu metode perencanaan dalam menyelenggaraan fasilitas parkir kendaraan baik di badan jalan (on street parking) maupun di luar badan jalan (off street parking).

\subsection{Perhitungan Karakteristik Parkir}

Adapun parameter yang mempengaruhi pemanfaatan lahan parkir (parking utilization) :

\subsubsection{Volume parkir}

Pengertian Volume parkir adalah jumlah kendaraan yang telah menggunakan ruang parkir pada suatu lahan parkir tertentu dalam suatu waktu tertentu (biasanya per hari). Perhitungan volume parkir dapat digunakan sebagai petunjuk apakah ruang parkir yang tersedia dapat memenuhi kebutuhan parkir kendaraan atau tidak (Hobbs, 1995). Berdasarkan volume tersebut maka dapat direncanakan besarnya ruang parkir yang diperlukan apabila akan dibuat pembangunan ruang parkir baru. Rumus yang digunakan adalah:

Volume $=\mathrm{E} i+\mathrm{X}$

Dimana:

$\mathrm{E} \mathrm{i}=$ Jumlah kendaraan yang masuk (kendaraan)

$\mathrm{X}=$ Kendaraan yang sudah ada sebelum waktu survai (kendaraan)

\subsubsection{Kebutuhan Ruang Parkir}

Analisis Kebutuhan Parkir Kebutuhan Ruang Parkir adalah jumlah tempat yang dibutuhkan untuk menampung kendaraan yang membutuhkan parkir berdasarkan fasilitas dan fungsi dari sebuah tata guna lahan. Untuk mengetahui kebutuhan parkir pada suatu kawasan yang di studi. Adapun analisis kebutuhan parkir ini dapat dihitung dengan menggunakan perhitungan sebagai berikut :

Rumus yang digunakan adalah :

$$
Z=\frac{Y \cdot D}{T}
$$

Keterangan:

$\mathrm{Z}=$ Ruang parkir yang dibutuhkan

$\mathrm{Y}=$ Jumlah kendaraan yang diparkir selama periode penelitian

$\mathrm{D}=$ Rata-rata durasi parkir

$\mathrm{T}=$ Lama waktu pengamatan

\subsubsection{Kebutuhan ruang parkir secara teoritis}

Pada kebutuhan ruang parkir secara teoritis dipengaruhi oleh jumlah kendaraan yang menggunakan fasilitas parkir, durasi parkir ratarata dan lamanya operasi parkir. Perhitungan jumlah ruang parkir yang dibutuhkan dapat pula didasarkan pada pendekatan rumus yang diperoleh dari Simposium III, ISBN no.979- 
96241-0-X,Hendro

(UGM;2000):

$$
\mathrm{Z}=\frac{\mathrm{F} \times \mathrm{D}}{T} .
$$

Dengan:

$\mathrm{Z}=$ ruang parkir yang dibutuhkan

(kendaraan)

$\mathrm{Y}=$ jumlah kendaraan yang parkir dalam waktu pengamatan

$\mathrm{D}=$ rata-rata durasi (menit)

$\mathrm{T}=$ lama pengamatan (menit)

\subsection{Metode Service Quality (ServQual)}

Penelitian ini disusun untuk mengarahkan pembahasan studi secara terstruktur.Metodologi penelitian digunakan untuk menganalisis dan mengklarifikasikan data dengan berbagai teknik seperti survey, observasi, literatur dan lain-lain. Metode Service Quality (ServQual) secara umum dan dipergunakan dalam bebagai bidang kajian karena kemudahan untuk diterapkan dan tampilan hasil analisa memudahkan usulan perbaikan kinerja/pelayanan. Servqual mempunyai fungsi utama mengukur seberapa baik suatu layanan menemui kecocokan dengan harapan pelanggan. Metode Analisa Service Quality (ServQual) mempunyai fungsi utama menampilkan informasi berkaitandengan informasi berkaitan dengan faktor - faktor pelayanan yang menurut responden sangat mempengaruhi kepuasan mereka dan faktor faktor pelayanan yang menurut koresponden perlu ditingkatkan bila kondisi saat ini belum memuaskan.

\section{METODOLOGI PENELITIAN}

\subsection{Pengukuran Harapan dan Kinerja}

Pengukuran Harapan dan Kinerja menggunakan rumus kualitas jasa dalam model Servqual ini didasarkan pada skala multi item yang dirancang untuk mengukur harapan dan aktual pengguna. Serta Gap diantara keduanya, dimana hal-hal tersebut dijabarkan dalam beberapa butir pertanyaan untuk atribut harapan dan variabel presepsi berdasarkan skala likert.

Skor Servqual untuk tiap pasang pertanyaan bagi masing-masing pengguna dapat dihitung berdasarkan rumus berikut (Zeithalm, et, al.,1990) dalam (Tjiptono

2008).

\section{SKOR SERVQUAL $=$ SKOR PERSEPSI - SKOR HARAPAN}

Skor Gap kualitas jasa pada berbagai level secara rinci dapat dihitung berdasarkan:

a. Item-by-item analysis, misal $\mathrm{P} 1-\mathrm{H} 1, \mathrm{P} 2$ - H2, dst. Dimana $\mathrm{P}=$ Persepsi dan $\mathrm{H}=$ Harapan

b. Dimensi-by-dimensi analysis, contoh: $(\mathrm{P} 1+\mathrm{P} 2+\mathrm{P} 3+\mathrm{Pn} / \mathrm{n})-(\mathrm{H} 1+\mathrm{H} 2+$ $\mathrm{H} 3+\mathrm{Hn} / \mathrm{n}$ dimana P1 sampai Pn dan H1 sampai $\mathrm{Hn}$ mencerminkan $\mathrm{n}$ pernyataan persepsi dan harapan berkaitan dengan dimensi tertentu.

c. Perhitungan ukuran tunggal kualitas jasa/gap servqual yaitu (P1+ P2 $+\mathrm{P} 3 \ldots+\mathrm{P} 22 / 22)-(\mathrm{H} 1+\mathrm{H} 2+\mathrm{H} 3$ $+\ldots .+\mathrm{H} 22 / 22)$

d. Untuk menganalisis kualitas akan jasa pelayanan yang telah diberikan, maka digunakan rumus.

\section{Persepsi (P)}

\section{Kualitas/Kinerja $=$ (rumus 2.1.) Harapan (H)}

Jika Kualitas (Q) $\geq 1$, maka kualitas pelayanan dikatakan baik.

\subsection{Uji Hipotesis}

Pengujian hipotesis dalam penelitian ini dilakukan dengan menggunakan uji $\mathrm{Z}$. Uji $\mathrm{Z}$ yang digunakan adalah uji $\mathrm{Z}$ dua sampel bebas atau paired sample t-test, yang berarti variabel berasal daripopulasi yang sama. (Ghozali, 2012). Kriteria pengujiannya adalah Jika $Z_{\text {hitung }} \geq Z_{\text {tabel }} ;-Z_{\text {hitung }}<-Z_{\text {tabel }}$ atau $\alpha<$ 0.05, maka Ha diterima dan Ho ditolak. Jika $Z_{\text {hitung }}<Z_{\text {tabel }} ;-Z_{\text {hitung }} \geq-Z_{\text {tabel }}$ atau $\alpha>0,05$ 
maka Ha ditolak dan Ho diterima.

\section{PEMBAHASAN}

\subsection{Analisa Tempat Parkir Stasiun Rambipuji.}

Tugas akhir ini membahas tentang Analisa Dan Tingkat Kepuasan Pengguna Ruang Parkir Pada Stasiun Kereta Api Rambipuji (DAOP IX Jember) dengan menggunakan metode Analisa Perhitungan dan Service Quality. Untuk kajian dalam hal ini membahas pula kondisi lalu lintas yang ada di ruas jalan Darmawangsa yang menjadi akses untuk menuju Stasiun. Untuk selanjutnya akan dilakukan analisa kinerja ruas jalan dijalan tersebut.

Adapun kendala teknis yang dialami oleh penulis yaitu terkait perijinan waktu penelitian yang hanya dari jam 08.00 dampai dengan 17.00 dan hanya 8 jadwal kedatangan dan keberangkatan kereta api yang teramati dari total 21 kereta api yang melewati Stasiun Kereta Api Rambipuji. Artinya hanya 38\% jadwal kereta api yang teramati.

\subsubsection{Volume Lalu Lintas Jalan Darmawangsa.}

Tabel 4.1 Data Volume Lalu Lintas 60 menit dari Jember-Tanggul dan Tanggul-Jember dalam satuan kendaraan/jam.

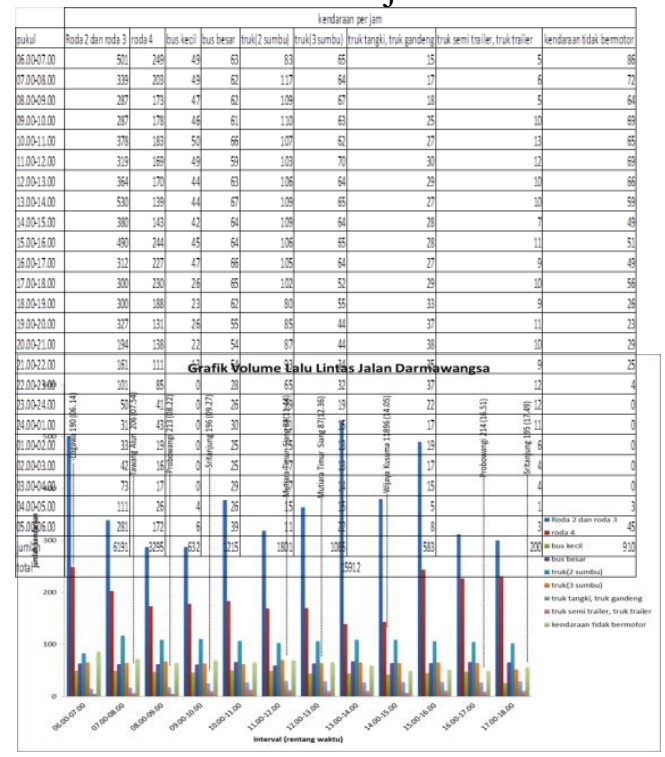

Gambar 4.1 Grafik Volume lalu lintas Jalan Darmawangsa pada jam 06.00-07.00 sampai

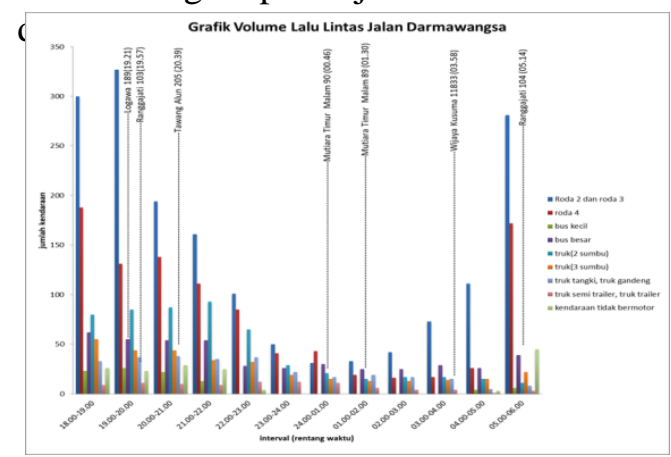

Gambar 4.2 Grafik Volume lalu lintas Jalan Darmawangsa pada jam 18.00-19.00 sampai dengan jam 05.00-06.00

\subsubsection{Kapasitas dan Derajat Kejenuhan Jalan Darmawangsa \\ 1. Kapasitas (C)}

Perhitungan kapasitas menggunakan persamaan dan langkah-langkah sesuai dengan petunjuk buku manual MKJI sebagai berikut: $\mathrm{C}=\mathrm{Co}$ X Fcw X FCsp X FCcs

\section{$\mathrm{Co}=3100$}

$\mathrm{FCw}=1$

FCsp $=1$

$\mathrm{FCsf}=1$

$\mathrm{FCcs}=1$

$\mathrm{C}=3100$

\section{Derajat Kejenuhan (degree of Saturation, DS)}

Derajat kejenuhan adalah perbandingan dari nilai volume (nilai arus) lalu lintas terhadap kapasitasnya. Berdasarkan definisi derajat kejenuhan, DS dihitung sebagai berikut :

$\mathrm{Q}=591,33$

$\mathrm{C}=3100$

$\mathrm{DS}=\mathrm{Q} / \mathrm{C}$

$=591,33 / 3100$

$=0,190752016 \mathrm{smp} / \mathrm{jam}$ 
Kepadatan untuk DS 5 tahun dari tahun 2018 sampai dengan 2023 dengan mengunakan $\mathrm{i}=5 \%$ dan menggunakan C 2019 yaitu 3100 .

Tabel 4.5 Data Volume Lalu Lintas untuk perencanaan DS 2023.

\begin{tabular}{|c|c|c|c|c|c|c|}
\hline No & Jenis Kendaraan & kendaraan per jam & $(1+0,05)^{\wedge 5}$ & LHR 2023 & EMP (MKII) & Qsmp 2023 \\
\hline 1 & Sepeda motor, skuter dan roda 3 & 257,9583 & 1,27628 & 329,2270191 & 0,25 & 82,30675478 \\
\hline 2 & Roda 4 & 137,29167 & 1,27628 & 175,2226126 & & 175,2226126 \\
\hline 3 & Bus Kecil & 26,3 & 1,27628 & 33,566164 & 1,2 & 40,2793968 \\
\hline 4 & Bus Besar & 50,625 & 1,27628 & 64,611675 & 1,2 & 77,53401 \\
\hline 5 & Trukl(2 sumbu) & 75,041 & 1,27628 & 95,77332748 & 1,2 & 114,927993 \\
\hline 6 & Truk(3 sumbu) & 45,2083 & 1,27628 & 57,69844912 & 1,2 & 69,23813895 \\
\hline 7 & Trukk tangki, truk gandengan & 24,29167 & 1,27628 & 31,00297259 & 1,2 & 37,20356711 \\
\hline 8 & TTuk seni triniler, truk traililer & 8,3 & 1,27628 & 10,593124 & 1,2 & 12,7117488 \\
\hline \multirow[t]{2}{*}{9} & Kendaran tidak bemmor & 37,9167 & 1,27628 & 48,39232588 & 3 & 145,1769776 \\
\hline & & & & & & 754,6011996 \\
\hline
\end{tabular}

DS2023 = Qsmp $/ C$

DS2023 $=754,6011996 / 3100$

DS2023 = 0,243419742 smp/jam

\subsubsection{Gambaran Umum Stasiun KAI Rambipuji}

Kondisi Eksisting Parkir Pada Stasiun

KAI Rambipuji berdasarkan pengamatan yang telah dilakukan di Stasiun KAI Rambipuji, jumlah ruang parkir yang tersedia untuk kendaraan roda 2 sebanyak 35 SRP dengan luas areal 53,91 $\mathrm{m}^{2}$ untuk kendaraan roda 4 dimensi mobil penumpang menggunakan Mobil Penumpang Untuk Golongan 3 yaitu 3,00 x 5,00 dan hasilnya adalah 13 SRP dengan luas areal $207,3352 \mathrm{~m}^{2}$. Gambar kondisi eksisting ada pada gambar 4.1 dan 4.2. Adapun Tipe Parkir yang dipakai pada Stasiun KAI Rambipuji yaitu :

a. Menurut tempatnya, parkir sepeda motor di Stasiun KAI Jember merupakan parkir off street parking.

b. Menurut posisi parkir, parkir R2 dan R4 bagian timur merupakan posisi parkir $90^{\circ}$ sedangkan untuk R4 barat bagian depan merupakan posisi parkir $60^{\circ}$.

c. Menurut statusnya, parkir di Stasiun KAI Rambipuji merupakan parkir khusus yaitu perparkiran yang menggunakan tanah-tanah yang dikuasai dan pengelolaanya diselenggarakan oleh pihak ketiga .

d. Menurut jenis kepemilikannya dan pengelolaanya, parkir di Stasiun KAI Rambipuji merupakan parkir yang dimiliki dan dikelola oleh swasta.
Penelitian yang dilakasanakan di Stasiun KAI Jember ini dilaksanakan mulai pada pukul 08:00 sampai 17:00. Sedangkan pelaksanaannya dilaksanakan selama 7 hari pada hari senin tanggal 10 Desember 2018 sampai dengan hari minggu tanggal 16 Desember 2018, Adapun data yang diperoleh dapat dilihat pada lampiran.

\subsubsection{Akumulasi Parkir}

Akumulasi Parkir adalah jumlah kendaraan yang parkir di suatu area pada waktu tertentu, yang besarnya dapat dihitung menggunakan rumus.Akumulasi Parkir sangat dipengaruhi oleh jumlah kendaraan yang keluar masuk area parkir pada periode waktu tertentu.

Tabel 4.10 Rangkuman Akumulasi Parkir Maksimum Sepeda Motor (R2)

\begin{tabular}{|c|c|c|c|c|}
\hline No & Hari & Tanggal & $\begin{array}{c}\text { Akumulasi Parkir } \\
\text { (Maksimum) }\end{array}$ & Rentang Waktu \\
\hline 1 & Senin & 10-Des-18 & 15 & $11.30-12.00$ \\
\hline 2 & Selasa & 11-Des-18 & 15 & $16.00-16.30$ \\
\hline 3 & Rabu & 12-Des-18 & 22 & $16.00-16.30$ \\
\hline 4 & Kamis & 13-Des-18 & 26 & $13.30-14.00$ \\
\hline 5 & Jumat & 14-Des-18 & 20 & $08.00-08.30$ \\
\hline 6 & Sabtu & 15-Des-18 & 27 & $12.00-12.30$ \\
\hline 7 & Minggu & 16-Des-18 & 22 & $11.30-12.00$ \\
\hline
\end{tabular}

Tabel 4.11 Rangkuman Akumulasi Parkir Maksimum Mobil (R4)

\begin{tabular}{|c|c|c|c|c|}
\hline No & Hari & Tanggal & $\begin{array}{c}\text { Akumulasi Parkir } \\
\text { (Maksimum) }\end{array}$ & Rentang Waktu \\
\hline 1 & Senin & 10-Des-18 & 4 & $11.30-12.00$ \\
\hline 2 & Selasa & 11-Des-18 & 7 & $16.00-16.30$ \\
\hline 3 & Rabu & 12-Des-18 & 4 & $16.00-16.30$ \\
\hline 4 & Kamis & 13-Des-18 & 7 & $13.30-14.00$ \\
\hline 5 & Jumat & 14-Des-18 & 6 & $08.00-08.30$ \\
\hline 6 & Sabtu & 15-Des-18 & 7 & $12.00-12.30$ \\
\hline 7 & Minggu & 16-Des-18 & 5 & $11.30-12.00$ \\
\hline Sumber - Analisa Perhitrtoggan
\end{tabular}

\subsubsection{Volume Parkir}

Tabel 4.12 Hasil Survey Volume Parkir Sepeda

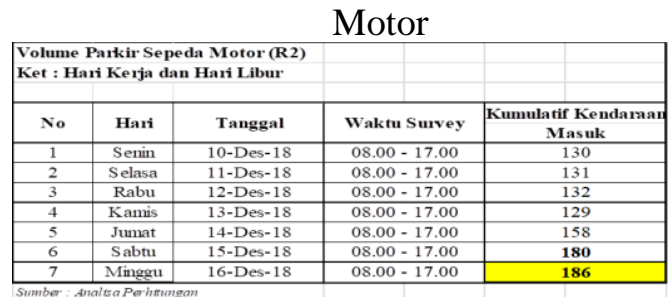

Tabel 4.13 Hasil Survey Volume Parkir Mobil

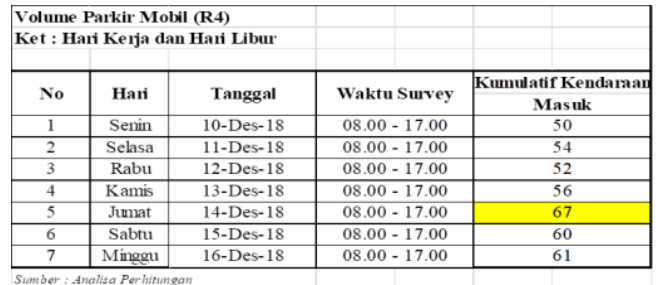




\subsubsection{Turn Over Parkir}

Tabel 4.14 Tingkat Turn Over Parkir Sepeda Motor

\begin{tabular}{|c|c|c|c|c|c|c|}
\hline \multicolumn{4}{|c|}{$\begin{array}{l}\text { Turn Over Parkir Sepeda Motor (R2) } \\
\text { Ket : Hari Kerja dan Hari Libur }\end{array}$} & & \multirow[b]{2}{*}{$\begin{array}{c}\text { Tum Over } \\
\text { Parkir } \\
\end{array}$} \\
\hline No & Hari & Tanggal & Waktu Surv & $\begin{array}{l}\text { Volume Parkir } \\
\text { (Kend) }\end{array}$ & $\begin{array}{l}\text { Kapasatias } \\
\text { Parkiri (SRP) }\end{array}$ & \\
\hline 1 & Senin & 10-Des-18 & $08.00-17.6$ & & 35 & \\
\hline & Selasa & 11-Des-18 & $08.00-17.6$ & 131 & 35 & 3,743 \\
\hline 3 & $\begin{array}{ll}\text { Rabu } \\
K\end{array}$ & 12-Des-18 & $08.00-17.6$ & 132 & 35 & 3,771 \\
\hline$\frac{4}{5}$ & $\begin{array}{l}\text { Kamis } \\
\text { Jumat } \\
\end{array}$ & 13-Des-18 & $08.00-17.6$ & $\frac{129}{158}$ & $\frac{35}{35}$ & 3,686 \\
\hline 6 & Sabtur & $\begin{array}{l}\text { 14-Deses-18 } \\
\text { 15-Des } 18\end{array}$ & $\begin{array}{l}0.800-1.6 \\
08.00-17.6\end{array}$ & $\frac{158}{180}$ & $\frac{35}{35}$ & $\begin{array}{r}5,14 \\
5,143 \\
\end{array}$ \\
\hline 7 & Minggu & 16-Des-18 & $08.00-17$. & 186 & 35 & 5,314 \\
\hline
\end{tabular}

Tabel 4.15 Tingkat Turn Over Parkir Mobil

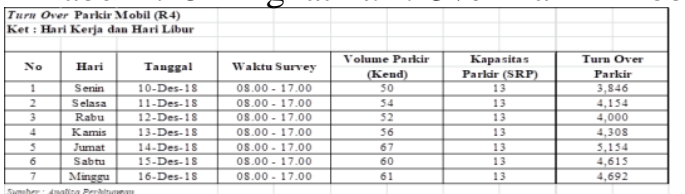

Tabel 4.16 Indeks Parkir Sepeda Motor

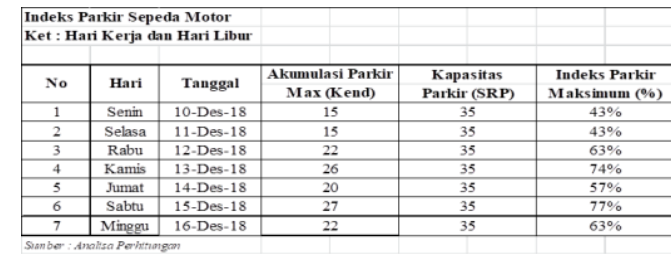

Tabel 4.17 Indeks Parkir Mobil

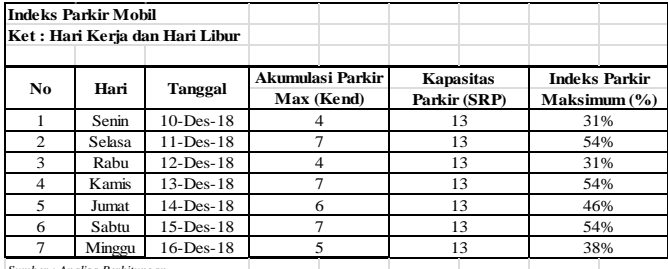

\subsubsection{Kebutuhan Ruang Parkir}

Dari observasi yang telah dilaksanakan diperoleh data primer yang selanjutnya diolah untuk menghitung kebutuhan ruang parkir di Stasiun KAI Rambipuji, Berdasarkan rangkuman analisa data sampai menghasilkan nilai kebutuhan parkir di Stasiun KAI Rambipuji sebagai berikut.

\subsubsection{Kebutuhan Parkir Roda 2 (Sepeda Motor)}

Tabel 4.18 Kebutuhan Parkir Sepeda Motor

\begin{tabular}{|c|c|c|c|c|c|c|c|c|c|c|}
\hline \multicolumn{11}{|c|}{ KEBUTUHAN PARKIR } \\
\hline \multicolumn{11}{|c|}{ 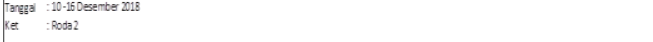 } \\
\hline \multirow{2}{*}{ No } & \multicolumn{2}{|l|}{ KEERAMGAN } & \multicolumn{7}{|c|}{ HAA } & \multirow{2}{*}{ Seturan } \\
\hline & & & sentents & SEASA & RABQU & & JuMat & & MIII6GU & \\
\hline & 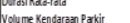 & y & 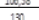 & 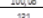 & 年 & 3.:53 & 10,20 & 19935 & 10049 & \\
\hline 3 & 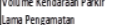 & T & $\frac{100}{540}$ & 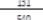 & $\frac{132}{1.2}$ & 18 & 188 & 1000 & 20 & Keedareer \\
\hline & 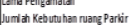 & $20.9 / 1$ & 2569 & 20 & 300 & 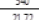 & 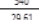 & 364 & 30 & \\
\hline 5 & Ruarg partic yag tessedia & SPP & 35 & 6,35 & 35 & $\frac{4,42}{35}$ & $\frac{204}{85}$ & 35 & 35 & Fendrem \\
\hline 6 & Tingkat Tum Over & To & $3,7.4$ & $3,7 / 3$ & $3,7 \mathrm{n}$ & 3005 & 4514 & 5.13 & 5314 & \\
\hline 7 & 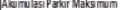 & AMax & & & & & & & & \\
\hline 8 & 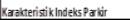 & & 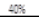 & $43_{3}$ & $63 \%$ & $7 \mathrm{~F}_{\mathrm{m}}$ & $5 \pi \mathrm{m}$ & $\pi / 4$ & 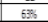 & \\
\hline
\end{tabular}

\subsubsection{Kebutuhan Parkir Roda 4}

Tabel 4.19 Kebutuhan Parkir Mobil

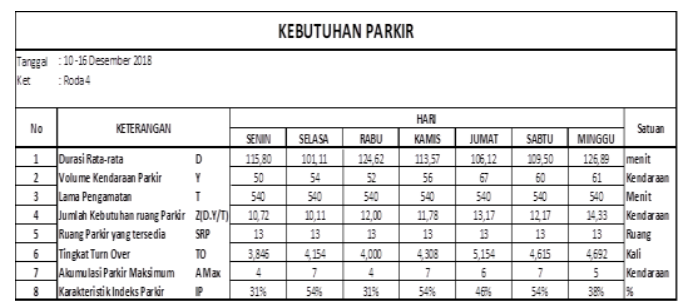

\subsubsection{Frekwensi Rata-Rata Aktual dan Harapan}

Aktual merupakan kejadian yang benar-benar terjadi, yaitu suatu kejadian yang baru saja terjadi atau yang sesungguhnya terjadi di lapangan. Harapan adalah keseluruhan dari kemampuan yang dimiliki individu untuk menghasilkan jalur mencapai tujuan yang diinginkan, bersamaan dengan motivasi yang dimiliki untuk menggunakan jalur-jalur tersebut.

Tabel 4.20 Frekwensi Rata-rata Aktual dan

\begin{tabular}{|c|c|c|c|}
\hline & \multicolumn{3}{|l|}{ Harapan } \\
\hline NO & INDIKATOR & AKTUAL & HARAPAN \\
\hline 1 & Kemampuan menampung sesuai kapasitas & 3,327 & 4,184 \\
\hline 2 & Kerapian penataan & 3,449 & 4,306 \\
\hline 3 & Kesigapan petugas mengatur kendaraan & 3,306 & 4,082 \\
\hline 4 & Pemberian karcis & 3,347 & 4,143 \\
\hline 5 & Dapat melayani klaim kehilangan & 2,939 & 4,408 \\
\hline 6 & Keamanan tempat parkir & 3,306 & 4,388 \\
\hline 7 & Pelayanan petugas & 3,204 & 4,184 \\
\hline 8 & Cepat tanggap saat terjadi komplain & 2,898 & 4,306 \\
\hline 9 & Kemampuan mengelola parkiran dengan jelas & 3,143 & 4,163 \\
\hline 10 & Kemampuan petugas mengatur tempat parkir & 3,306 & 4,122 \\
\hline 11 & Kebersihan tempat parkir & 3,245 & 4,102 \\
\hline 12 & Tata letak kendaraan parkir & 3,143 & 4,102 \\
\hline 13 & garis letak parkir, rambu informasi dll & 3,000 & 3,980 \\
\hline 14 & Seragam resmi petugas & 2,633 & 3,878 \\
\hline 15 & Bantuan petugas parkir & 3,265 & 3,519 \\
\hline 16 & Komunikasi antara petugas dan pengguna & 3,122 & 3,939 \\
\hline 17 & Respon terhadap keluhan pengguna & 2,918 & 4,184 \\
\hline 18 & Pelayanan parkir lebih dari 1 hari & 1,347 & 4,000 \\
\hline 19 & Fasilitas pos penjagaan & 1,347 & 4,020 \\
\hline
\end{tabular}

\subsubsection{Hasil Uji Hipotesis}

Uji hipotesis adalah membandingkan antara nilai $\mathrm{Z}$ hitung dengan nilai $\mathrm{Z}$ tabel, dalam konteks penelitian tempat parkir pada Stasiun Rambipuji ini nilai signifikansinya adalah 5 persen dan 1 persen. Nilai $Z$ tabel untuk nilai signifikansi 5\% sebesar 1,96, sedangkan $Z$ tabel untuk nilai signifikansi sebesar 1 persen sebesar 2,57. Pada penelitian ini uji hipotesis dilakukan untuk 2 (dua) sisi. Ada tiga kategori akhir sebagai kesimpulan dari perbandingan $\mathrm{Z}$ hitung dan $\mathrm{Z}$ tabel, pertama non significant (NS) atau 
disebut juga dengan tidak berbeda nyata apabila nilai $\mathrm{Z}$ hitungnya anatara 1,96 dan $-1,96$, yang kedua bila nilainya diatas 2,57 dan dibawah 2,57 maka disebut dengan berbeda sangat nyata, ketiga apabila nilainya diantara 1,96 dan 2,57 serta $-1,96$ dan $-2,57$ maka disebut berbeda nyata.

Tabel 4.2 Tabel Hasil Uji Hipotesis

\begin{tabular}{r|l|r|l|}
\hline NO & INDIKATOR & ZHITUNG & KETERANGAN \\
\hline 1 & Kemampuan menampung sesuai kapasitas & $-4,389$ & $* *$ \\
\hline 2 & Kerapian penataan & $-4,307$ & $* *$ \\
\hline 3 & Kesigapan petugas mengatur kendaraan & $-3,596$ & $* *$ \\
\hline 4 & Pemberian karcis & $-3,844$ & $* *$ \\
\hline 5 & Dapat melayani klaim kehilangan & $-5,993$ & $* *$ \\
\hline 6 & Keamanan tempat parkir & $-4,795$ & $* *$ \\
\hline 7 & Pelayanan petugas & $-5,233$ & $* *$ \\
\hline 8 & Cepat tanggap saat terjadi komplain & $-6,237$ & $* *$ \\
\hline 9 & Kemampuan mengelola parkiran dengan jelas & $-5,136$ & $* *$ \\
\hline 10 & Kemampuan petugas mengatur tempat parkir & $-3,172$ & $* *$ \\
\hline 11 & Kebersihan tempat parkir & $-3,554$ & $* *$ \\
\hline 12 & Tata letak kendaraan parkir & $-4,181$ & $* *$ \\
\hline 13 & garis letak parkir, rambu informasi dII & $-3,953$ & $* *$ \\
\hline 14 & Seragam resmi petugas & $-5,461$ & $* *$ \\
\hline 15 & Bantuan petugas parkir & $-4,483$ & $* *$ \\
\hline 16 & Komunikasi antara petugas dan pengguna & $-3,586$ & $* *$ \\
\hline 17 & Respon terhadap keluhan pengguna & $-6,067$ & $* *$ \\
\hline 18 & Pelayanan parkir lebih dari 1 hari & $-17,441$ & $* *$ \\
\hline 19 & Fasilitas pos penjagaan & $-14,966$ & $* *$ \\
\hline
\end{tabular}

Keterangan:

NS $=$ Non significant (Tidak Berbeda Sangat Nyata)

*) = Berbeda Tidak Nyata

$* *) \quad=$ Berbeda Sangat Nyata

\section{KESIMPULAN}

\subsection{Kesimpulan}

Berdasarkan hasil survey dan analisis data yang dilakukan, dapat ditemukan beberapa kesimpulan pada Stasiun KAI Rambipuji sebagai berikut :

1. - Nilai DS 2018 pada jalan Darmawangsa depan stasiun Rambipuji yaitu 0,1907520 smp/jam, masuk pada tingkat pelayanan A.

- $\quad$ Nilai DS 2023 yaitu sebesar 0,243419742 smp/jam, masuk pada tingkat pelayanan B.
- Kapasitas statis ruang parkir di Stasiun KAI Rambipuji untuk sepeda motor sebesar 35 SRP, untuk mobil sebesar 13 SRP.

- Volume dan akumulasi parkir maksimum

- Volume maksimum sepeda motor terjadi pada hari Minggu yaitu dengan nilai sebesar 186 Kendaraan dengan akumulasi tertinggi pada hari Sabtu dengan nilai sebesar 27 dengan rentang waktu $12.00-$ 12.30 .

- Volume parkir maksimum mobil terjadi pada hari Jumat yaitu dengan nilai sebesar 67 Kendaraan dengan akumulasi tertinggi pada hari selasa dengan rentang waktu 16.00 - 16.30, kamis dengan rentang waktu 13.30 - 14.00, dan sabtu dengan rentang $12.00-12.30$.

- Turn over parkir kendaraan sepeda motor di Stasiun KAI Rambipuji dengan nilai 0 sampai 5 dalam sehari untuk kendaraan sepeda motor. Hal ini menunjukkan bahwa kinerja parkir sepeda motor tinggi. Namun untuk mobil mencapai nilai 0 sampai 5 dalam sehari. Dalam hal ini kinerja parkir untuk kendaran mobil tinggi.

- Indeks parkir untuk kendaraan sepeda motor berkisar antara 43\% - 77\%. Hal ini menunjukkan bahwa kapasitas statis ruang parkir sepeda motor di Stasiun KAI Rambipuji masih dapat memenuhi kebutuhan parkir yang ada. Sedangkan indeks parkir mobil berkisar antara $31 \%$ 54\%. Hal ini menunjukan bahwa kapasitas statis ruang parkir mobil di Stasiun KAI Rambi puji masih dapat memenuhi kebutuhan parkir yang ada.

- Durasi parkir

- Sepeda motor terjadi dengan rentang waktu 0 s/d 180 menit pada hari senin, selasa, kamis, jumat, sabtu dan hari minggu dan pada hari rabu terjadi dengan rentang waktu $0 \mathrm{~s} / \mathrm{d}>240$ menit.

- Mobil terjadi dengan rentang waktu $0 \mathrm{~s} / \mathrm{d}$ 180 menit pada hari senin, selasa, kamis, jumat, dan hari sabtu dan pada hari rabu dan hari minggu terjadi dengan rentang waktu 0 s/d >240 menit.

- Kebutuhan ruang parkir berdasarkan kapasitas statis untuk sepeda motor sebesar 
35 SRP untuk mobil 13 SRP, dan belum dapat dipenuhi oleh ruang parkir Stasiun KAI Rambipuji, karena ruang parkir tersebut mengasilkan nilai masing-masing kebutuhan parkirnya yaitu sepeda motor $38 \mathrm{SRP}$, mobil 14 SRP. Hal ini menunjukan bahwa kebutuhan ruang parkir di Stasiun KAI Rambipuji, tidak dapat memenuhi kebutuhan parkir tersebut, Tetapi untuk nilai SRP tersebut tidak terlalu jauh dengan nilai SRP statis sebelumnya.

2. Hasil analisis service quality yang dilakukan untuk evaluasi tempat parkir Stasiun KAI Rambipuji dengan menggunakan 49 sampel pengguna parkiran. Penilaian tempat parkir Stasiun Rambipuji diasumsikan berdasarkan hasil kuesioner responden sehingga dapat diidentifikasi kendala-kendala yang menyebabkan buruknya kualitas tempat parkir Stasiun KAI Rambipuji. Adapun beberapa indikator yang di berikan kepada responden diantaranya yaitu kemampuan menampung sesuai kapasitas, kerapian penataan parkir, kesigapan petugas mengatur kendaraan, pemberian karcis parkir, pelayanan klaim kehilangan kendaraan, keamanan tempat parkir, pelayanan petugas parkir, cepat tanggap saat terjadi komplain, kemampuan mengelola tempat parkir, kebersihan tempat parkir, tata letak parkir kendaraan, garis letak parkir rambu informasi parkir dan lain-lain, seragam resmi petugas parkir, bantuan petugas parkir, komunikasi antara petugas dengan pengguna, respon petugas terhadap keluhan pengguna parkir, pelayanan untuk kendaraan parkir lebih dari 1 hari, fasilitas pos penjagaan untuk petugas parkir. Penilaian aktual dan harapan pengguna tempat parkir untuk membuat tempat parkir menjadi sangat baik kedepannya, terbukti dari hasil olah data kuisioner dari total 49 data responden yang diolah didapat nilai rata-rata aktual 2,960 dan nilai rata-rata harapan 4,144, nilai rata-rata aktual lebih kecil daripada nilai rata-rata harapan yang artinya responden sangat mengharapkan perubahan yang sangat nyata pada tempat parkir Stasiun KAI Rambipuji. Kualitas indikator yang ada pada kuesioner tidak ada yang lebih dari nilai 1 (satu) itu menandakan semua indikator memiliki kualitas yang buruk/bermasalah.

3. Uji hipotesis adalah membandingkan $\mathrm{Z}$ hitung dengan $\mathrm{Z}$ tabel. Pada uji hipotesis ini penyusun memilih $Z$ tabel 5 persen dan 1 persen. Nilai $Z$ tabel signifikansi 5 persen sebesar 1,96 dan -1,96, sedangkan $Z$ tabel dengan nilai signifikan 1 persen sebesar 2,57. Pada penelitian ini uji hipotesis dilakukan untuk 2 (dua) sisi. Ada tiga kategori akhir sebagai kesimpulan dari perbandingan $\mathrm{Z}$ hitung dan $\mathrm{Z}$ tabel, pertama non significant (NS) atau disebut juga dengan tidak berbeda nyata apabila nilai $\mathrm{Z}$ hitungnya anatara 1,96 dan -1,96, yang kedua bila nilainya diatas 2,57 dan dibawah -2,57 maka disebut dengan berbeda sangat nyata, ketiga apabila nilainya diantara 1,96 dan 2,57 serta -1,96 dan -2,57 maka disebut berbeda nyata. Secara keseluruhan semua indikator yang termasuk kedalam kategori sangat berbeda nyata. Karena tidak ada indikator yang berada pada $\mathrm{Z}$ tabel untuk nilai $5 \%$ sebesar 1,96 , dan $Z$ tabel untuk nilai sebesar 1 persen sebesar 2,57.

\subsection{Saran}

1. Daya tampung kendaraan parkir stasiun Rambipuji ini perlu ditambah agar lebih optimal lagi pada saat kondisi puncak.

2. Perlu adanya pelayanan parkir lebih dari 1 hari dan penerapan sistem e-gate satu pintu masuk dan satu pintu keluar pada area parkir stasiun Rambipuji untuk menunjang kinerja dari tempat parkir.

3. Perbaikan pada semua indikator yang ada pada kuesioner untuk menunjang kinerja kedepannya agar lebih baik lagi.

4. Disarankan untuk penelitian kedepan waktu yang dilakukan harus 24 jam agar lebih detail lagi dan lebih baik. 
Trijoyo. 2000. Analisis Kebutuhan Parkir di Daerah Pasar. TA SI Teknik Sipil (tidak dipublikasikan). UGM Jogjakarta,

Munawar, Ahmad 2004, Program Komputer Untuk Analisis LaluLintas, Beta Offset, Jogjakarta

Gunasti, A., 2017. Penilaian Kinerja Tukang dan Harapan Mandor dalam Proyek Konstruksi. Jurnal Penelitian IPTEKS, 2(1).

\section{DAFTAR PUSTAKA}

Agus. 2002. Kebutuhan Ruang Parkir Sepeda Motar di RS Sardjito Jogjakarta. TA SI Teknik Sipil (tidak dipublikasikan). UGM Jogjakarta.

Badan Pusat Siatistik Kota Semarang. 2004. Kota Semarang dalam Angka Tahun 2004. Semarang.

Direktorat Jenderal Perhubungan Darat, Departemen Perhuhungan RI, 1996. Pedoman Teknis Penyelenggaraan Fasilitas Parkir. Jakarta

Menteri/Sekretaris Negara RI. 1992 UndangUndang Repubtik Indonesia Nomor 14 Tahun 1992 tentang lalu lintas dab Angkutan Jalan, Jakarta

Hobbs, F.D 1979. Traffic Planning and Engineering, Second Edition. Terjemahan oleh Suprapto TM dan Waldjono Penerbit Gajah Mada Press, Yogyakarta.

Pignataro, Louis J. 1973. Traffic Engineering, theory and practice. Prentice-Hall, Inc. United States of America

Prasetyo, 2000. Analisis Kebutuhan Parkir di Lngkungan UGM. TA SI Teknik Sipil (tidak dipublikasikan). UGM Jogjakarta

Samosir. 1998. Tinjauan Penyediaan Fasilitas Parkir Pada Kawasan Malioboro. TA SI Teknik Sipil (tidak dipublikasikan). UGM Jogjakarta, 